\title{
Natural infections of small mammals with blood parasites on the borderland of boreal and temperate forest zones
}

\author{
Grzegorz KARBOWIAK, Leszek RYCHLIK, Wojciech NOWAKOWSKI and Irena WITA
}

Karbowiak G., Rychlik L., Nowakowski W. and Wita I. 2005. Natural infections of small mammals with blood parasites on the borderland of boreal and temperate forest zones. Acta Theriologica 50: 00-00.

Blood parasites of small mammals living in Białowieża Forest (eastern Poland) were investigated between 1996 and 2002. The following haemoparasite species were found: Trypanosoma (Herpetosoma) evotomys in bank vole Clethrionomys glareolus and root vole Microtus oeconomus; Babesia microti in root vole; Hepatozoon erhardovae in bank vole and Hepatozoon sp. in root vole. Some non-identified Bartonella species were found in bank vole, root vole, field vole Microtus agrestis, yellow-necked mouse Apodemus flavicollis, common shrew Sorex araneus, Eurasian water shrew Neomys fodiens, and Mediterranean water shrew $N$. anomalus. The prevalence and diversity of blood parasites were lower in shrews than small rodents. Totally, $52.0 \%$ of bank voles, $50.0 \%$ of root voles, $32.5 \%$ of common shrews, and $41.2 \%$ of Eurasian water shrews were infected with any of the blood parasites. Mixed infections were seldom observed in bank vole (17.3\% of investigated individuals) and root vole $(14.7 \%)$. No animals were infected with three or four parasites simultaneously. Infection of Białowieża small mammals with haemoparasites seemed to be similar to those described in other temperate forest regions rather than boreal ones. Infection rates of rodent species seem to be higher in their typical habitats: for bank vole it was the highest in mixed forest, whereas for root vole in sedge swamp. The results suggest that Microtidae play a greater role than Muridae or Soricidae in maintenance of Babesia and Hepatozoon foci in natural environments of central Europe.

W. Stefański Institute of Parasitology, Polish Academy of Sciences, Twarda 51/55, 00-818 Warsaw, Poland, e-mail: grzgrz@twarda.pan.pl (GK, IW); Mammal Research Institute, Polish Academy of Sciences, 17-230 Białowieża, Poland, e-mail: lrychlik@bison.zbs.bialowieza.pl (LR); Department of Biology, University of Podlasie, Prusa 12, 08-110 Siedlce, e-mail: koszatek@poczta.onet.pl (WN) 
Key words: rodents, shrews, haematozoa, blood parasites, primeval forest

\section{Introduction}

Wild rodents are known to carry various pathogens which can be transmitted to man. However, little data exists about the role of small mammals in disseminating vectortransmitted blood parasites. In Poland, the occurrence of many parasites in rodents and shrews has been studied as part of ecological surveys on small mammals. Parasitological investigations of small mammals living in Białowieża Forest have been conducted since the second part of 20th century. They covered mainly the ectoparasites (Lachmajer and Wegner 1956, Lachmajer 1959, Wegner 1959) and helmints (Kisielewska 1963, 1964, 1970). The first study of blood parasites were made in mid-1990s only (Karbowiak et al. 2002). Blood parasites of shrews have not been reported from Poland before; however, there are reports from elsewhere (eg Laakkonen 2000).

Białowieża Forest is one of the last primeval forest complexes in western and middle Europe. Moreover, it is an especially interesting place for biological investigations due to the geographical location on the borderland of the boreal and temperate forest zones. This fact results in the mix of fauna and flora from both zones (Faliński 1968,1986, Gutowski and Jaroszewicz 2001, 2004). For example, among small mammals, masked shrew Sorex caecutiens - a boreal species - reaches its south-western limit in this area, whereas for Mediterranean water shrew Neomys anomalus and bi-coloured white-toothed shrew Crocidura leucodon, Białowieża Forest is the north-eastern boundary (Pucek 1981, MitchellJones et al. 1999). The same can be expected for ecto- and endoparasites of small mammals. A typical taiga tick, Ixodes persulcatus, has its western limit in Belarussia and Lithuania, however single findings were noted in Białowieża (Siuda 1993). Therefore, we expected the differences in the structure or biological features of blood parasite fauna in comparison with other parts of Europe.

The aims of this study were: (1) To describe the protozoan parasites living in the blood of small rodents and shrews. A mixture of parasitological faunas typical for boreal and temperate forest zones was expected. (2) To compare prevalence and diversity of blood parasites in shrews and rodents. Higher prevalence and diversity were predicted in rodents because they are more social than shrews (Eisenberg 1966, Crook et al. 1976, Rychlik 1998), so more frequent parasite exchange should occur in rodents. (3) To investigate parasite 
infection levels in different habitats. A higher prevalence was expected in habitats optimal for given species, due to higher densities of conspecifics and thus a higher risk of parasite transmission.

\section{Material and methods}

One-week trapping sessions of small rodents and shrews were conducted in four areas: area 1 - Czerlonka (mixed forest, compartment 491 of the Białowieża Forest; in June 1996 and June 1997), area 2 - Knihiniówka (ash-alder forest and sedge swamp, compartment 426; June, July and August 1996), area 3 - Podolany (bank of old river arm, between Białowieża and Podolany villages; August 2002), and area 4 - Reski (sedge swamp, compartment 398; August 2002). The mammals were caught in live-traps placed at permanent trap stations arranged in a rectangular grid or line. Traps were placed and set (without pre-baiting) in the afternoon, checked four times per day, and blocked after a final check around midnight.

Captured mammals were individually identified and released after collection of blood samples. Animals previously caught in the same session were immediately released. Blood samples were taken from the tip of tail and thin smears prepared. Smears were air-dried, fixed in methyl alcohol and stained for 1 hour with Giemsa, diluted (1:5) in phosphate buffer, $\mathrm{pH}$ 7.2. Slides were rinsed in buffer, dried and examined under a light microscope.

For measurements of parasites, "Analysis" software, in combination with a video camera and Olympus BX50F4 microscope, was used. This method affords possibilities for obtaining the measurements with accuracy to $0.01 \mu \mathrm{m}$. Stained blood smears were analysed at a magnification of $800 \times$ and $1500 \times$. For each slide, about 50 fields were examined. Measurements were done on 100 parasite specimens. Terminology adapted by other researchers (Hoare 1972, Matthews et al. 1977, Kingston et al. 1992) was employed to characterise morphological features of protozoa found in the present study.

\section{Results}

A total of 158 small mammals (including 52 individuals of bank vole Clethrionomys glareolus, 34 root voles Microtus oeconomus, 2 field voles Microtus agrestis, 6 yellownecked mice Apodemus flavicollis, 2 northern birch mice Sicista betulina, 40 common shrews Sorex araneus, 4 pygmy shrews Sorex minutus, 17 Eurasian water shrews Neomys fodiens, and 1 Mediterranean water shrew Neomys anomalus) were examined (Table 1). The following haemoparasite species were found: Trypanosoma (Herpetosoma) evotomys Hadwen, 1912 in 
bank vole; Trypanosoma (Herpetosoma) microti Laveran and Pettit, 1909 in root vole; piroplasma Babesia microti in root vole; Hepatozoon erhardovae in bank vole, Hepatozoon sp. in root vole (Fig. 1). A number of non-identified bacteria, belonging to Bartonella genus were found in bank, root and field voles, yellow-necked mouse, common shrew, Eurasian and Mediterranean water shrews (Fig. 2, Table 1). Totally, $52.0 \%$ of bank voles, $50.0 \%$ of root voles, $32.5 \%$ of common shrews, and $41.2 \%$ of Eurasian water shrews were infected with any of the blood parasites.

Trypanosomes were found in rodents only. The prevalence of infection of bank vole with $T$. (H.) evotomys ranged from $2.7 \%$ (area 2 ) to $25 \%$ (area 1 ). The prevalence of infection of root vole with $T$. (H.) microti ranged from $21.4 \%$ (area 2 ) to $50 \%$ (area 4). The trypanosomes appeared in peripheral blood streams in the trypomastigota form (Fig. 1a, b). The detailed measurement parameters of trypanosomes are showed in Table 2.

Infection with Babesia microti was detected only in root vole. The prevalence of infection varied from $7.1 \%$ (area 2) to $50 \%$ (area 4). The mean intensity of the erythrocyte infection was $2.5 \%$. The parasites were mostly of the ring-like and pear-shaped form (the morphological terminology after Mehlhorn and Schein 1984) and were 1.5-3.0 $\mu \mathrm{m}$ in diameter (Fig. 1c, d). Dividing stages, which occurred rarely, were 2.5-3.5 $\mu \mathrm{m}$ in diameter. Usually one parasite was seen in infected erythrocyte. The regular form of four cells "maltese cross", characteristic for "small" Babesia species, was seldom noticed. The infected animals did not show any noticeable pathological symptoms. However, during post mortem examination of some voles, accidentally died in the traps, a high degree of splenomegaly was observed (the size of the spleen was $25 \times 15 \mathrm{~mm}$ in infected and 14-16 $\times 3-5 \mathrm{~mm}$ in noninfected root voles).

The gametocytes of Hepatozoon erhardovae were found inside leucocytes of bank and root voles (Table 1). The prevalence was relatively high (up to $41.6 \%$ in area 1). Root voles were infected with Hepatozoon sp. only in area 2 with low prevalence (7.1\%). Only single parasite was seen in infected lymphocytes (Fig. 1e, f). The measurements of Hepatozoon sp. are presented in Table 3.

The Bartonella bacterias were found in nearly all mammal species investigated (Table 1). The prevalence of infection in rodents was high, especially in their optimal habitats (66.6\% in yellow-necked mouse and $41.7 \%$ in bank vole from area 1, 37.5\% in root vole from area 4). In contrast, root voles from areas 1 and 3 were not infected. The infection with Bartonella seemed to be also high in common shrew and Eurasian water shrew. It was 
detected in Mediterranean water shrew and field vole, whereas not in pygmy shrew and birch mouse, but these results are based on too small samples. The bacteria found in Eurasian water shrew (mean $1.5 \times 0.4 \mu \mathrm{m}$, range 0.6-1.7 $\times 0.2-0.7 \mu \mathrm{m}$ ) were bigger than in bank vole, field vole, yellow-necked mouse, and common shrew $(0.9 \times 0.4 \mu \mathrm{m}$, range 0.5-1.6 $\times 0.1-0.8 \mu \mathrm{m}$; Fig. 2). The mean number of bacteria per single infected erythrocyte was lower in bank vole, field vole and Eurasian water shrew (16-17) than in yellow-necked mouse and common shrew (19-20).

Mixed infections, with two parasite species, were observed in bank vole and root vole. There were the following combinations of parasitism: Trypanosoma sp. + Bartonella sp., Trypanosoma sp. + Babesia sp., Babesia sp. + Bartonella sp., Hepatozoon sp. + Bartonella sp. All combinations were found in $14.7 \%$ of investigated root voles, and Trypanosoma sp. + Bartonella sp. and Hepatozoon sp. + Bartonella sp. in $17.3 \%$ of investigated bank voles. There were $36.5 \%$ of bank voles and $35.3 \%$ of root voles infected with one parasite species, whereas $46.2 \%$ of bank voles and $50.0 \%$ of root voles were not infected. No animals were infected with three and four parasites simultaneously.

\section{Discussion}

The prevalence of bank vole infection with Trypanosoma evotomys (up to $25.0 \%$ on area 1) was relatively high in Białowieża Forest. Our results are in accordance to data from former Czechoslovakia, Austria and Great Britain (Šebek 1975, Šebek et al. 1980, Frank 1978, Healing 1981, Turner 1986), but higher than from Norway (0-16.7\% in summer - Wiger 1979). However, the infection with Herpetosoma trypanosomes depends on season (Turner 1986, Karbowiak and Wita 2001). T. evotomys was relatively rare in bank vole in spring (0.9\% - Šebek 1975, Šebek et al. 1980) and frequent in late summer (Baker et al. 1963, Karbowiak and Wita 2001). The prevalence of T. microti was higher in root vole from Białowieża Forest (21.4-50.0\%) than those noted for field vole (0.9-12.8\% - Baker et al. 1963, Šebek 1975, Healing 1981) and common vole Microtus arvalis (9.0\% - Pawelczyk et al. 2004). However, some authors showed the between-year variability in prevalence of this parasite (Wiger 1979, Pawelczyk et al. 2004).

In Białowieża, the Babesia microti infection was found in root vole only, but with a high frequency (up to $50.0 \%$ ). The prevalence of $B$. microti in field vole ranged from 13.5 to $30.5 \%$ in temperate forest zone (Baker et al. 1963, Cox 1970, Krampitz and Bäumler 1978, Šebek et al. 1980, Healing 1981), was $14.6 \%$ in boreal zone of Europe (Wiger 1979), and 
amounted only $9.0 \%$ in common vole from Mazurian Lakeland, northern Poland (Pawelczyk et al. 2004). Simultaneously, these authors, as well as Bajer et al. (2001) noted the low prevalence or lack of $B$. microti infection in other co-existing small mammals. This supports the great role of Microtus voles in maintenance of zoonotic babesiosis foci in natural environments in central Europe (Karbowiak et al. 1999, Pawelczyk et al. 2004).

A high degree of splenomegaly observed in root vole corresponds with the previous observations that splenomegaly is a characteristic symptom of mammals infected with $B$. microti (Fay and Rausch 1969, Krampitz and Bäumler 1978, Watkins et al. 1991). Some authors correlate splenomegaly to infections with all blood parasites (eg Wiger 1978); however, we have not observed this phenomenon in animals infected with Trypanosoma or Hepatozoon. Apart splenomegaly symptoms, voles infected with Babesia displayed no other visible signs, so it is evident that piroplasms cause chronic avirulent infections in its natural hosts (Fay and Rausch 1969, Krampitz and Bäumler 1978, Turner 1986).

Hepatozoon spp. were detected in bank vole and root vole but not in yellow-necked mouse and insectivores. The prevalence of infection of bank vole in Białowieża (18.9-41.6\%) was similar or lower than described in other temperate regions (28.2-56.0\%; Šebek 1975, Healing 1981, Turner and Cox 1985), and similar or higher than in boreal ones (2.5-36.6\% Wiger 1979, 18-55\% - Laakkonen et al. 2001). Our measurements of $H$. erhardovae in bank vole are in accordance with description given by Krampitz (1964). The prevalence of Hepatozoon sp. in root vole tended to be higher in Białowieża (7.1\%) than in root vole (2\% Laakkonen et al. 2002) and field vole (4.2\% - Wiger 1979) from northern regions. Based on morphology (Table 3), it is impossible to include the Hepatozoon found in our root voles to H. microti Coles, 1914 or H. lavieri (Brumpt, 1946), two species described in field and common voles, respectively (Krampitz 1964). Similarly to our findings, in other studies Hepatozoon was not detected in wood mouse Apodemus sylvativus (Wiger 1979) and insectivores (Laakkonen et al. 2002), thus it can be concluded that Microtidae play a greater role in maintenance of Hepatozoon than Muridae or Soricidae.

The prevalence of Bartonella infection in rodents can be as high as $>60 \%$ (Breitschwerdt and Kordick 2000). In Białowieża, this infection seemed to be higher in yellow-necked mouse (66.6\%) and field vole (50\%) than in bank vole (27.7-41.7\%) and root vole (7.1-37.5\%). Similar results (above 25\% in seasonal peak of infections) have been obtained in Great Britain (Baker 1974, Healing 1981), Austria (Šebek et al. 1980), and northern Poland (Bajer et al. 2001, Pawelczyk et al. 2004). In contrast, lower infection was 
observed in summer months in Norway: ca $10 \%$ of wood mice, $32 \%$ of field voles and $24 \%$ of bank voles (Wiger 1979).

The high prevalence of Bartonella infection was also detected in insectivores from Białowieża: $32.4-50.0 \%$ of common shrews and $46.6 \%$ of Eurasian water shrews were infected. So far, the Bartonella infection of Sorex shrews has been found in central (Šebek et al. 1980) and northern Europe (Laakkonen 2000) as well as North America (Breitschwerdt and Kordick 2000, Laakkonen et al. 2002), but the values were lower (2-20\%). There are few probable reasons of the differences among localisations and mammal taxa: (1) the different composition of ectoparasites (especially dominant species of mites or fleas) in particular regions and on rodents and insectivores (Haitlinger 1983, 1984); (2) specific local conditions influencing the host-parasite interactions; and (3) blood parasites sampled from live (this study) versus dead animals (most other studies). Thus, these issues requires further investigations.

Bartonella species are very similar morphologically (Breitschwerdt and Kordick 2000). Except for the bigger bacteria from Eurasian water shrew, the mean sizes of bartonellas from Białowieża Forest did not differ. Moreover, we observed a quite high variability in number of bacteria per infected cell. These facts suggest that our mammals were infected with different Bartonella species. However, we did not identify the bacteria found because these parasites are not host-specific and cases of co-infection of one host with some Bartonella species have been reported (Birtles et al. 1994, Breitschwerdt and Kordick 2000).

The above literature survey showed many similarities in haemoparisite infection of small mammals between Białowieża and other regions of temperate forests, as well as some differences in comparison to the boreal zone. Usually, the infection rates of both rodents and shrews with particular parasites were lower in boreal zone than in Białowieża. Also, the total infection of rodents with all types of the blood parasites seemed to be lower in northern regions (eg about 30\% for bank vole - Wiger 1979) than in Białowieża (about 50\%). Laakkonen et al. (2002) observed a similar phenomenon and suggested that it is caused by an absence of vectors in arctic areas. On the other hand, in Białowieża we have not found haemoparisites of typical boreal inhabitants, as for example Trypanosoma lemmi living on lemmings (Wiger 1978). Thus, although data on blood parasites of small mammals from the boreal zone are scarce, we can conclude that the haemoparasitic infections in Białowieża were similar to those described in other regions of temperate forests rather than boreal ones.

Some small mammals investigated have been mix-infected with two parasite species. However, the number of mixed infections is relatively low in comparison to the whole 
number of infected rodents. The most common co-infection was Hepatozoon+Bartonella in bank vole. Other combinations, as well as co-infections in other host species, were seldom. Consistently with our prediction, the prevalence and diversity of blood parasites were higher in rodents (social) than shrews (asocial). Similar results were found by other authors (Cox 1970, Baker 1974, Turner 1986). This corresponds to higher infection rates and diversities of ectoparasites in rodents than shrews (Haitlinger 1983, 1984, Stanko 1989, Stanko at al. 2002).

Deciduous and mixed forests are the optimal habitats for bank vole, whereas sedge swamps and wet meadows are optimal for root vole (Pucek 1981, Rychlik 2001). The densities of these species were the highest in the mentioned habitats, respectively (eg Aulak 1970). Consistently with our prediction, parasite infections found in the present study were also higher in optimal then sub-optimal habitats: for bank vole they were higher in mixed forest (area 1) than in the three wet habitats (areas 2-4), whereas for root vole an opposite situation was observed, with the highest infection rates in sedge swamp (area 4). The differences in infection rates observed between the three wet habitats could result, for example, from local environmental conditions that may influence the dominance structure, prevalence of infestation and seasonal dynamics of ectoparasites (Haitlinger 1981) and, in turn, the blood parasites.

We would like to point out that, considering the factors described above, it is very difficult to describe the full picture of blood parasite infection of small mammals under natural conditions. Unfortunately, there are only few data about ecological factors (flora components, humidity etc.) in parasitological studies (Bajer et al. 2001, Karbowiak and Wita 2001, Pawelczyk et al. 2004). The infection with blood parasites depends also on the age of animals (Krampitz and Bäumler 1978, Healing 1981, Turner 1986, Bajer et al. 2001, Pawelczyk et al. 2004). By these reasons, single observations are often insufficient and can give false results. It is therefore necessary to conduct annual thorough investigations of selected mammal populations in order to obtain detailed data about infection with blood parasites, as well as their carriers.

Acknowledgements: We are very grateful to M. Hajdul, K. Ostrowska, I. Smerczyński, E. Sorato, and R. Zwolak for their field and technician assistance, S. Prior for language consultation. This study was supported by funds of the IP PAS, MRI PAS and by grant no. 6 P04F 03621 from the Committee for Scientific Research. 


\section{References}

Aulak W. 1970. Small mammal communities of the Białowieża National Park. Acta Theriologica 15: 465-515.

Bajer A., Pawelczyk A., Behnke J., Gilbert F. and Sinski E. 2001. Factors affecting the component community structure of haemoparasites in bank voles (Clethrionomys glareolus) from the Mazury Lake District region of Poland. Parasitology 122: 43-54.

Baker J. R. 1974. Protozoan parasites of the blood of British wild birds and mammals. Journal of Zoology, London 172: 169-190.

Baker J. R., Chitty D. and Phipps E. 1963. Blood parasites of wild voles, Microtus agrestis, in England. Parasitology 53: 297-301.

Birtles R. J., Harrison T. G. and Molyneux D. H. 1994. Grahamella in small woodland mammals in the UK: isolation, prevalence and host specificity. Annales of Tropical and Medical Parasitology 88: 317-327.

Breitschwerdt E. B. and Kordick D. L. 2000. Bartonella infection in animals: carriership, reservoir potential, pathogenicity, and zoonotic potential for human infection. Clinical Microbiology Review 13: 428-438.

Cox F. E. G. 1970. Parasitic protozoa of British wild mammals. Mammal Review 1: 1-28.

Crook J. H., Ellis J. E. and Goss-Custard J. D. 1976. Mammalian social systems: structure and function. Animal Behaviour 24: 261-274.

Eisenberg J. F. 1966. The social organizations of mammals. [In: Handbuch der Zoologie. Eine Naturgeschichte der Stämme des Tierreiches. Helmcke J.-G., Lengerken H., Starck D. and Wermuth H., eds]. Walter de Gruyter \& Co., Berlin, Band 8, Tail 10: 1-92.

Faliński J. B. (ed) 1968. The National Park in Białowieża Primeval Forest. PWRiL, Warsaw: 1-504. [In Polish]

Faliński J. B. (ed) 1986. Vegetation dynamics in temperate lowland primeval forests.

Ecological studies in Białowieża forest. Dr W. Junk Publishers, Dordrecht: 1-537.

Fay F. H. and Rausch R. L. 1969. Parasitic organisms in the blood of arvicoline rodents in Alaska. Journal of Parasitology 55: 1258-1265.

Frank C. 1978. Kleinsäugerprotozoen im Neusiedlerseegebiet. Angewandte Parasitologie 19: 137-154.

Gutowski J. M. and Jaroszewicz B. (eds) 2001. Catalogue of the fauna of Białowieża Primeval Forest. Forestry Research Institute, Warsaw: 1-403. 
Gutowski J. M. and Jaroszewicz B. 2004. [Białowieża Primeval Forest as a refugium of European insect fauna]. Wiadomości Entomologiczne 23, Suppl. 2: 67-87. [In Polish] Haitlinger R. 1981. Structure of arthropod community occuring on Microtus arvalis (Pall.) in various habitats. I. Faunistic differentiation, dominance structure, arthropod infestation intensiveness in relation to habitats and host population dynamics. Polish Ecological Studies 7: 271-292.

Haitlinger R. 1983. Invertebrates associated with the bank vole. Arthropod communities. [In: Ecology of the bank vole. Petrusewicz K., ed]. Acta Theriologica 28, Suppl. 1: 55-68. Haitlinger R. 1984. [Parasitic arthropods of Neomys fodiens (Penn.) and Neomys anomalus Cabr. (Mammalia, Insectivora) in Poland]. Wiadomości Parazytologiczne 30: 603-616. [In Polish]

Healing T. D. 1981. Infections with blood parasites in the small British rodents Apodemus sylvaticus, Clethrionomys glareolus and Microtus agrestis. Parasitology 83: 179-189. Hoare C. A. 1972. The trypanosomes of mammals. IX. The Stercoraria. Subgenus Herpetosoma Doflein, 1901. Blackwell Scientific Publications, Oxford, Edinburgh: 214-326. Karbowiak G., Rychlik L., Wita I. and Czaplińska U. 2002. The blood parasites and their vectors in rodents living in wet habitats in Białowieża Forest. [In: Materials of the $4^{\text {th }}$ International Symposium "Parasitic, allergenic and venomous arthropods - their medical and sanitary significance", Kazimierz Dolny, 6-9.05.2002]. Medical Academy of Lublin, Lublin: 36-37.

Karbowiak G., Stanko M., Rychlik L., Nowakowski W. and Siuda K. 1999. The new data about zoonotic reservoir of Babesia microti in small mammals in Poland. Acta Parasitologica 44: $142-144$.

Karbowiak G. and Wita I. 2001. [Ecological aspects of the infection of bank vole Clethrionomys glareolus (Schreber, 1780) with Trypanosoma (Herpetosoma) evotomys Hadwen, 1912]. Wiadomości Parazytologiczne 47: 789-795. [In Polish] Kingston N., Bobek B., Perzanowski K., Wita I. and Maki L. 1992. Description of Trypanosoma (Megatrypanum) stefanskii sp. n. from Roe Deer (Capreolus capreolus) in Poland. Journal of the Helminthological Society of Washington 59: 89-95.

Kisielewska K. 1963. Food composition and reproduction of Sorex araneus Linnaeus, 1758 in the light of parasitological research. Acta Theriologica 7: 127-153.

Kisielewska K. 1964. Changes in the structure of cestodofauna of Sorex araneus araneus L. from the Białowieża National Park due to climatic conditions in 1960. Acta Parasitologica Polonica 12: 33-46. 
Kisielewska K. 1970. Ecological organization of intestinal helminth groupings in Clethrionomys glareolus (Schreb.) (Rodentia). II. An attempt at an introduction of helminths of $C$. glareolus from the Białowieża National Park into an island of the Bełdany Lake (Mazurian Lakeland). Acta Parasitologica Polonica 18: 149-162.

Krampitz H. E. 1964. Über das Vorkommen und Verhalten von Haemococcidien der Gattung Hepatozoon Miller 1908 (Protozoa, Adeleidea) in mittel- und südeuropäischen Säugern. Acta Tropica 21: 114-154.

Krampitz H. E. and Bäumler W. 1978. Vorkommen, Saisondynamik und Wirtskreis von Babesia microti (França, 1912) in einheimischen Nagetieren. Zeitshrift für Parasitenkunde 58: 15-33.

Laakkonen J. 2000. Microparasites of three species of shrews from Finnish Lapland. Annales Zoolologici Fennici 37: 37-41.

Laakkonen J., Henttonen H., Hastriter M. W., Niemimaa J. and Jarrel G. H. 2002.

Hemoparasites and fleas of shrews and rodents from Alaska. Acta Parasitologica 47: 255-257. Laakkonen J., Sukura A., Oksanen A., Henttonen H. and Soveri T. 2001. Haemogregarines of the genus Hepatozoon (Apicomplexa: Adeleina) in rodents from northern Europe. Folia Parasitologica 48: 263-267.

Lachmajer J. 1959. Fleas of small mammals in natural focus of tick-born encephalitis in the Puszcza Białowieska (National Park). Biuletyn Instytutu Medycyny Morskiej w Gdańsku 10: $5-14$.

Lachmajer J. and Wegner Z. 1956. [Fauna of fleas and louses parasitizing small mammals of Białowieża National Park]. Wiadomości Parazytologiczne 5 (suppl): 103-104. [In Polish] Matthews M. J., Kingston N. and Morton J. K. 1977. Trypanosoma cervi Kingston and Morton, 1975 from mule deer, Odocoileus hemionus, in Wyoming. Journal of Wildlife Diseases 13: 33-39.

Mehlhorn H. and Schein E. 1984. The piroplasms: life cycle and sexual stages. Advances in Parasitology 74: 151-158.

Mitchell-Jones A. J., Amori G., Bogdanowicz W., Kryštufek B., Reijnders P. J. H., Spitzenberger F., Stubbe M., Thissen J. B. M., Vohralík V. and Zima J. (eds) 1999. The atlas of European mammals. T and AD Poyser Ltd, London: 1-484.

Pawelczyk A., Bajer A., Behnke J. M., Gilbert F. S. and Sinski E. 2004. Factors affecting the component community structure of haemoparasites in common voles (Microtus arvalis) from the Mazury Lake District region of Poland. Parasitology Research 92: 270-284.

Pucek Z. (ed.) 1981. Keys to vertebrates of Poland. Mammals. PWN - Polish Scientific 
Publishers, Warszawa: 1-367.

Rychlik L. 1998. Evolution of social systems in shrews. [In: Evolution of shrews. Wójcik J.

M. and Wolsan M., eds]. Mammal Research Institute, Polish Academy of Sciences,

Białowieża: 347-406.

Rychlik L. 2001. Habitat preferences of water shrews and root vole coexisting along a stream in Białowieża Forest. Säugetierkundliche Informationen, Jena 5: 99-112.

Šebek Z. 1975. Blutparasiten der wildlebenden Kleinsäuger in der Tschechoslowakei. Folia Parasitologica 22: 11-20.

Šebek Z., Sixl W., Stünzner D., Valová M., Hubálek Z. and Troger H. 1980. Zur Kenntnis der Blutparasiten wildlebender Kleinsäuger in der Steiermark und im Burgenland. Folia Parasitologica 27: 295-301.

Siuda K. 1993. [Ticks of Poland (Acari: Ixodida). II. Systematics and distribution]. Polish Parasitological Society, Warszawa: 1-381. [In Polish]

Stanko M. 1989. [Mites (Acarina, Mesostigmata) of small mammals in two West Carpathian regions]. Biologia, Bratislava 44: 499-512. [In Slovak]

Stanko M., Miklisová D., Bellocq J. G. and Morand S. 2002. Mammal density and patterns of ectoparasite species richness and abundance. Oecologia, Berlin 131: 289-295.

Turner C. M. R. 1986. Seasonal and age distributions of Babesia, Hepatozoon, Trypanosoma and Grahamella species in Clethrionomys glareolus and Apodemus sylvaticus populations. Parasitology 93: 279-280.

Turner C. M. R. and Cox F. E. G. 1985. Interspecific interactions between blood parasites in a wild rodent community. Annales of Tropical Medicine and Parasitology 79: 463-465.

Watkins R. A., Moshier S. E., O'dell W. D. and Pinter A. J. 1991. Splenomegaly and reticulocytosis caused by Babesia microti infections in natural populations of the Montane vole, Microtus montanus. Journal of Protozoology 38: 573-576.

Wegner Z. 1959. Lice on small mammals in natural focus of tick-born encephalitis in the Puszcza Białowieska (National Park). Biuletyn Instytutu Medycyny Morskiej w Gdańsku 10: 31-38.

Wiger R. 1978. Hematological, splenic and adrenal changes associated with natural and experimental infections of Trypanosoma lemmi in the Norwegian lemming, Lemmus lemmus (L.). Folia Parasitologica (Praha) 25: 295-230.

Wiger R. 1979. Seasonal and annual variations in the prevalence of blood parasites in cyclic species of small rodents in Norway with special reference to Clethrionomys glareolus. Holarctic Ecology 2: 169-175. 
Table 1. Infection rates with blood parasites of small mammals captured between June 1996 and August 2002 at four study areas within Białowieża Forest (E Poland). The number of animals infected/examined, as well as percent infected are shown. $n$-number of individuals examined, ${ }^{1)}$ the species names of the genera Trypanosoma and Hepatozoon, found in particular species of small mammals, are detailed in the text, ${ }^{2)}$ sample size statistically insignificant.

\begin{tabular}{|c|c|c|c|c|c|c|c|c|c|}
\hline Mammal species & $n$ & \multicolumn{2}{|c|}{$\begin{array}{l}\text { Trypanosoma } \\
\text { spp. }{ }^{1)}\end{array}$} & \multicolumn{2}{|c|}{$\begin{array}{c}\text { Babesia } \\
\text { microti }\end{array}$} & \multicolumn{2}{|c|}{$\begin{array}{c}\text { Hepatozoon } \\
\text { spp. }{ }^{1)}\end{array}$} & \multicolumn{2}{|c|}{$\begin{array}{l}\text { Bartonella } \\
\text { spp. }\end{array}$} \\
\hline \multicolumn{10}{|c|}{ Area 1 (mixed forest) } \\
\hline C. glareolus & 12 & $3 / 12$ & $(25.0 \%)$ & - & - & $5 / 12$ & $(41.6 \%)$ & $5 / 12$ & $(41.7 \%)$ \\
\hline M. oеconomus & 6 & $2 / 6$ & $(33.3 \%)$ & $2 / 6$ & $(33.3 \%)$ & - & - & - & - \\
\hline A. flavicollis & 6 & - & - & - & - & - & - & $4 / 6$ & $(66.6 \%)$ \\
\hline
\end{tabular}

Area 2 (ash-alder forest and sedge swamp)

\begin{tabular}{lccccccccc}
\hline C. glareolus & 37 & $1 / 37$ & $(2.7 \%)$ & - & - & $7 / 37$ & $(18.9 \%)$ & $10 / 37$ & $(27.7 \%)$ \\
M. oeconomus & 14 & $3 / 14$ & $(21.4 \%)$ & $1 / 14$ & $(7.1 \%)$ & $1 / 14$ & $(7.1 \%)$ & $1 / 14$ & $(7.1 \%)$ \\
S. araneus & 37 & - & - & - & - & - & - & $12 / 37$ & $(32.4 \%)$ \\
S. minutus & 4 & - & - & - & - & - & - & - & - \\
N. fodiens & 17 & - & - & - & - & - & - & $7 / 15$ & $(46.6 \%)$ \\
N. anomalus & 1 & - & - & - & - & - & - & $1 / 1$ & $(100 \%)^{2}$ \\
\hline
\end{tabular}

Area 3 (old river arm)

\begin{tabular}{lccccccccc}
\hline C. glareolus & 3 & - & - & - & - & $1 / 3$ & $(33.3 \%)$ & $1 / 3$ & $(33.3 \%)$ \\
M. oeconomus & 6 & $2 / 6$ & $(33.3 \%)$ & - & - & - & - & - & - \\
M. agrestis & 2 & - & - & - & - & - & - & $1 / 2$ & $(50 \%)^{2)}$ \\
S. betulina & 2 & - & - & - & - & - & - & - & - \\
S. araneus & 2 & - & - & - & - & - & - & $1 / 2$ & $(50 \%)^{2)}$ \\
\hline
\end{tabular}

Area 4 (sedge swamp)

\begin{tabular}{lccccccccc}
\hline M. oeconomus & 8 & $4 / 8$ & $(50.0 \%)$ & $4 / 8$ & $(50 \%)$ & - & - & $3 / 8$ & $(37.5 \%)$ \\
S. araneus & 1 & - & - & - & - & - & - & - & - \\
\hline
\end{tabular}


Table 2. Measurements (in $\mu \mathrm{m}$ ) and size indices of Trypanosoma evotomys from stained films of the blood of bank vole Clethrionomys glareolus and T. microti from blood of root vole Microtus oeconomus caught in Białowieża Forest (E Poland). Measurements: PK posterior end to kinetoplast, $\mathrm{KN}$ - kinetoplast to nucleus centre, $\mathrm{PN}$ - posterior end to nucleus centre, NA - nucleus centre to anterior end, BL - body length, FF - free flagellum length, L - total length, $\mathrm{N}$ - nucleus length, $\mathrm{W}$ - width of body on the nucleus level excluding the undulating membrane. Indices: nuclear index NI = PN / NA, kinetoplastic index $\mathrm{KI}=\mathrm{PN} / \mathrm{KN}$, flagellar index FF:BL.

\begin{tabular}{|c|c|c|c|c|c|c|c|}
\hline \multirow{2}{*}{$\begin{array}{c}\text { Trypanosoma } \\
\text { species }\end{array}$} & \multicolumn{7}{|c|}{ Parameter } \\
\hline & & PK & $\mathrm{KN}$ & $\mathrm{PN}$ & NA & BL & $\mathrm{FF}$ \\
\hline \multirow{2}{*}{$\begin{array}{c}\text { T. evotomys } \\
n=100\end{array}$} & mean & $3.26 \pm 0.29$ & $7.66 \pm 0.51$ & $10.92 \pm 0.52$ & $10.50 \pm 1.46$ & $21.43 \pm 1.47$ & $6.23 \pm 1.42$ \\
\hline & range & $2.87-3.73$ & $6.98-8.70$ & $10.05-11.74$ & $8.20-12.18$ & $19.37-23.28$ & $3.99-8.71$ \\
\hline \multirow{2}{*}{$\begin{array}{c}\text { T. microti } \\
n=100\end{array}$} & mean & $4.31 \pm 0.53$ & $6.44 \pm 0.71$ & $10.74 \pm 0.79$ & $10.92 \pm 1.15$ & $21.66 \pm 1.48$ & $8.50 \pm 0.99$ \\
\hline & range & $2.68-6.06$ & $3.58-8.14$ & $7.93-12.65$ & $8.03-14.07$ & $17.36-25.76$ & $6.14-11.31$ \\
\hline \multirow{2}{*}{$\begin{array}{c}\text { Trypanosoma } \\
\text { species }\end{array}$} & \multicolumn{7}{|c|}{ Parameter } \\
\hline & & $\mathrm{L}$ & $\mathrm{N}$ & W & NI & KI & FF:BL \\
\hline T. evotomys & mean & $27.56 \pm 1.47$ & $3.03 \pm 0.26$ & $1.12 \pm 0.18$ & $1.06 \pm 0.17$ & $1.43 \pm 0.05$ & $3.63 \pm 0.92$ \\
\hline$n=100$ & range & $24.15-29.10$ & $2.65-3.61$ & $0.83-1.53$ & $0.88-1.36$ & $1.35-1.51$ & $2.22-5.05$ \\
\hline T. microti & mean & $30.16 \pm 1.36$ & $2.77 \pm 0.44$ & $1.57 \pm 0.48$ & $0.99 \pm 0.12$ & $1.67 \pm 0.15$ & $2.59 \pm 0.41$ \\
\hline$n=100$ & range & $25.09-33.00$ & $1.09-3.94$ & $0.87-3.38$ & $0.75-1.40$ & $1.26-2.22$ & $1.76-3.79$ \\
\hline
\end{tabular}


Table 3. Measurements (in $\mu \mathrm{m}$ ) of Hepatozoon erhardovae and Hepatozoon sp. from stained films of the blood of bank vole Clethrionomys glareolus and root vole Microtus oeconomus caught in Białowieża Forest (E Poland).

\begin{tabular}{lllll} 
Parasite & & Length & Width & Nucleus length $\times$ width \\
\hline H. erhardovae from & mean & $9.4 \pm 0.8$ & $3.4 \pm 0.4$ & $4.8 \pm 0.7 \times 2.5 \pm 0.4$ \\
C. glareolus & range & $8.4-11.0$ & $2.8-4.3$ & $2.4-6.0 \times 1.8-3.8$ \\
\hline H. sp. from & mean & $9.4 \pm 0.5$ & $3.3 \pm 0.4$ & $4.8 \pm 0.4 \times 2.4 \pm 0.3$ \\
M. oeconomus & range & $8.0-10.4$ & $2.4-3.9$ & $4.0-5.7 \times 1.7-2.9$
\end{tabular}




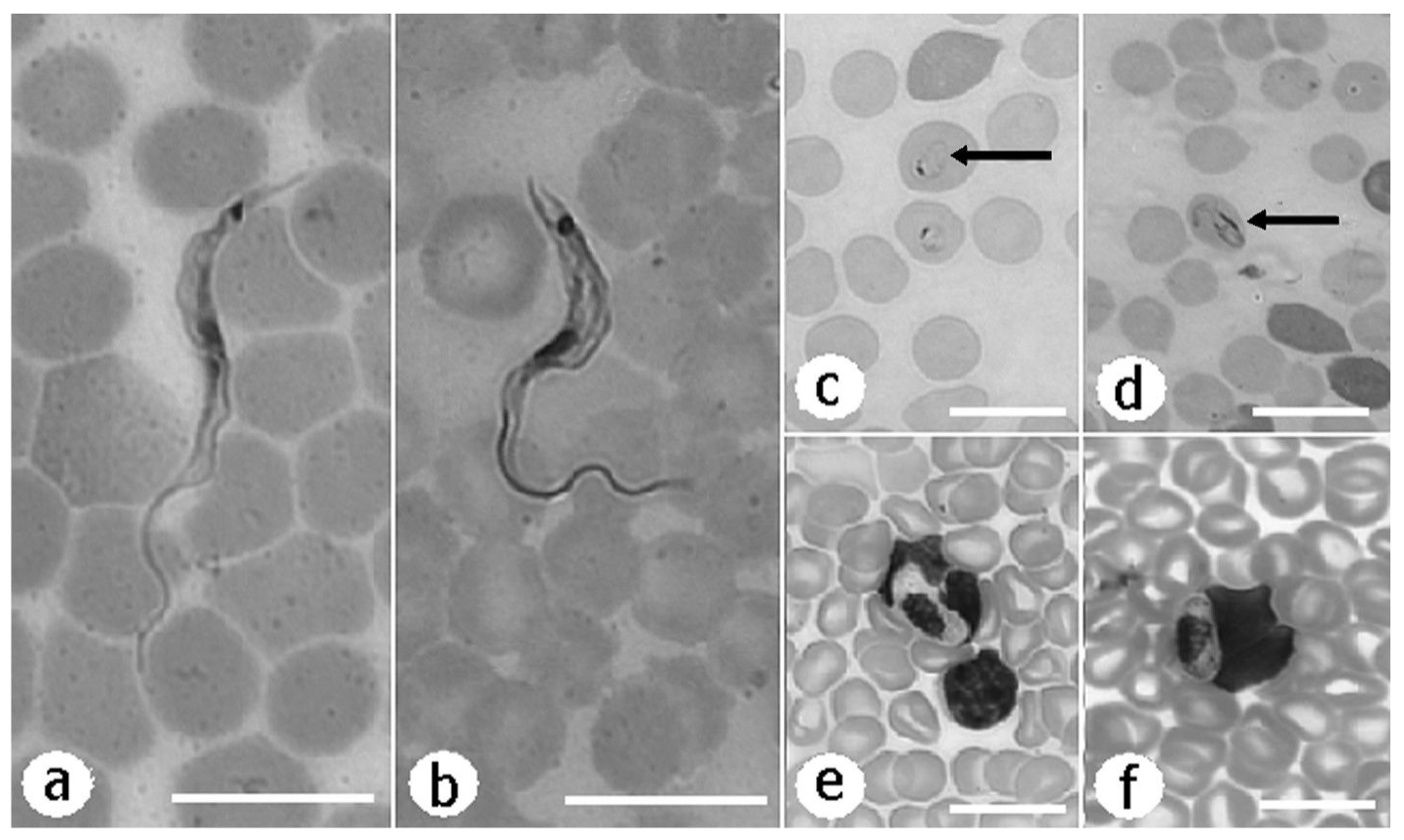

Fig. 1. Blood parasites of small rodents from Białowieża Forest (E Poland): (a) Trypanosoma evotomys from bank vole, (b) Trypanosoma microti from root vole, (c) ring-like and (d) pearshaped forms of Babesia piroplasms detected in root vole, (e) Hepatozoon erhardovae from bank vole, (f) Hepatozoon sp. from root vole. Scale bars $=10 \mu \mathrm{m}$. 


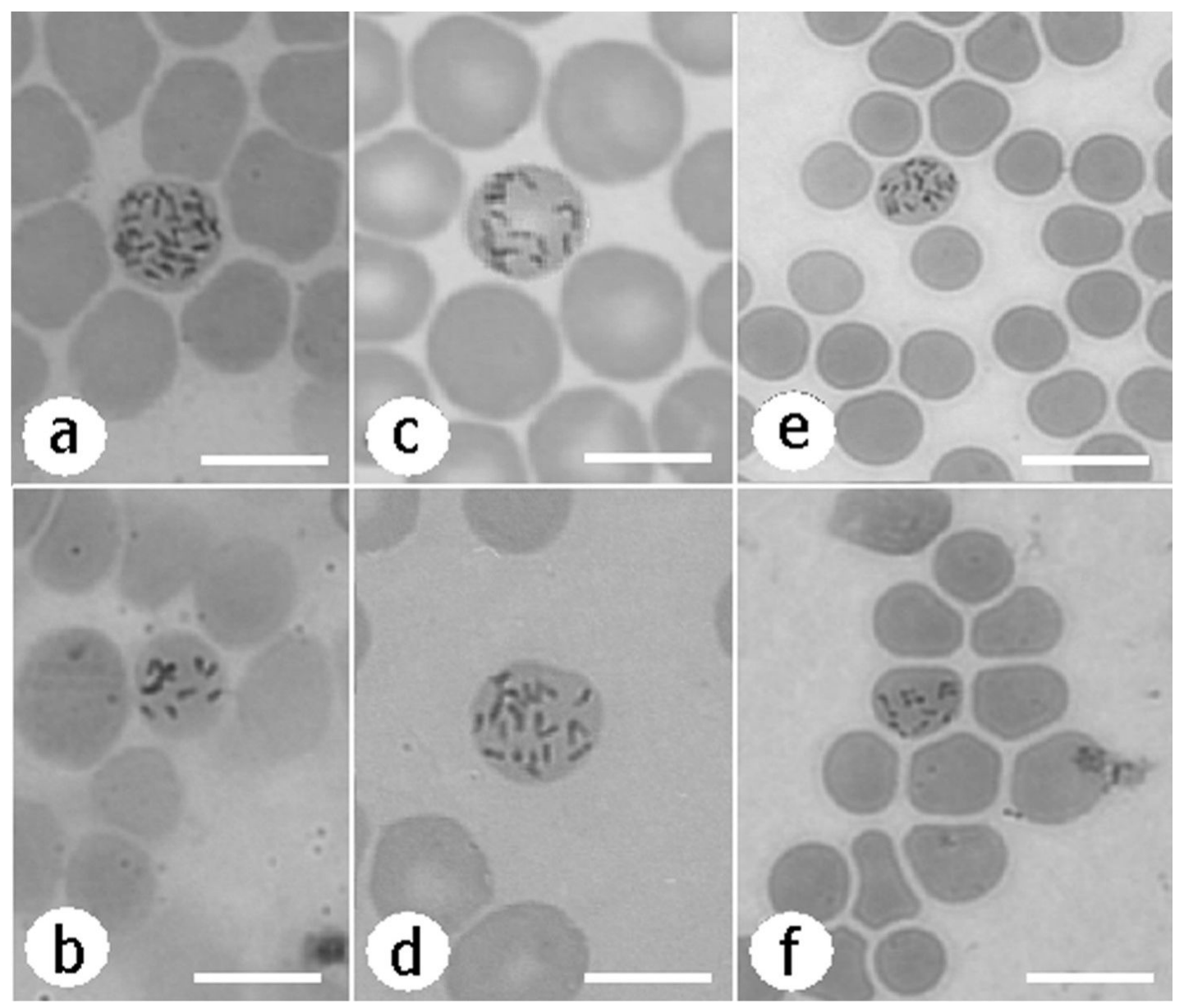

Fig. 2. Bartonella sp. detected in erythrocytes of small rodents and insectivores from Białowieża Forest (E Poland): (a, b) bank vole, (c) root vole, (d) yellow-necked mouse, (e) common shrew, (f) Eurasian water shrew. Scale bars $=5 \mu \mathrm{m}$. 